\title{
BIORETENTION AS A CONTROL TO URBAN DRAINAGE SYSTEM WITH AN ECOHYDROLOGICAL BASE: GIS AS A TOOL ON DECISION MAKING
}

\author{
Altair Rosa \\ Professor and researched at the Undergraduate Program in Environmental Engineering \\ Pontifícia Universidade Católica do Paraná (PUCPR) \\ 1155 Imaculada Conceição St. \\ PO box: 16210 . \\ City: Curitiba - State: Paraná - Zip Code: 80215-901 \\ Email: altair.rosa17@gmail.com \\ ORCID: https://orcid.org/0000-0002-0036-5363 \\ CV: http://lattes.cnpq.br/8497841698526810 \\ Mario Procopiuck \\ Professor and Researcher at the Postgraduate Program in Urban Management \\ Pontifícia Universidade Católica do Paraná (PUCPR) \\ 1155 Imaculada Conceição St. \\ PO box: 16210 . \\ City: Curitiba - State: Paraná - Zip Code: 80215-901 \\ Email: mario.p@pucpr.br \\ ORCID: http://orcid.org/0000-0002-7346-1938 \\ CV: http://lattes.cnpq.br/2464341539930740 \\ Marina Batalini de Macedo \\ Doctoral student, Hydraulic Engineering and Sanitation, University of Sao Paulo \\ Email address: marina_batalini@usp.br \\ ORCID: https://orcid.org/0000-0003-2829-754X \\ CV: http://lattes.cnpq.br/9996626534431250 \\ David Sample \\ Associate Professor and Extension Specialist, Department of Biological Systems Engineering, \\ Virginia Tech \\ Email address: dsample@vt.edu \\ ORCID: https://orcid.org/0000-0003-4533-9588 \\ CV: https://www.bse.vt.edu/about/people/tenured_and_tenure_track_faculty/sample_david.html \\ César Ambrogi Ferreira do Lago \\ Doctoral student, Hydraulic Engineering and Sanitation, University of Sao Paulo \\ Email address: cesar-lago@ hotmail.com \\ ORCID: https://orcid.org/0000-0002-0387-0226 \\ CV: http://lattes.cnpq.br/3154830315789267 \\ Vladimir Caramori de Souza \\ Professor and Researcher at the Federal University of Alagoas Graduate Program In Water Resources \\ And Sanitation - PPGRHS / UFAL \\ Email address: vcaramori@yahoo.com \\ ORCID: https://orcid.org/0000-0003-2143-5081 \\ CV: http://lattes.cnpq.br/7649240510556136 \\ Mario Eduardo Mendiondo \\ Professor and Researcher at the University of Sao Paulo - Hydraulic Engineering and Sanitation \\ Email address: emm@sc.usp.br \\ ORCID: https://orcid.org/0000-0003-2319-2773 \\ 54 CV: http://lattes.cnpq.br/5966392470702563
}



ECOHYDROLOGICAL BASE: GIS AS A TOOL ON DECISION MAKING

The occupation and use of increasingly impermeable urban land have made it difficult to infiltrate water and, consequently, increase the volume of runoff in different cities, which has required the development of bioretention techniques in the field of hydrology. The aim of this article is to define and apply criteria for the identification of areas for the construction of Bioretention systems for evaluations based on Geographic Information System indicators, considering the aspects of quantity and quality in urban drainage. The developed method allows to verify and compare changes in the surface of urban areas and their interference in the local environment, the mapping of land use and occupation to simplify procedures to define and prioritize areas for the construction of Bioretention systems, the use of resources from georeferenced bases to resolve eco-hydrological issues. The study develops technical bases for the use of a georeferencing tool to analyze areas with speed and consistency as a basis for decisions on the implementation of Bioretention systems. urban waters. 
Since the 1960s, urban drainage began to appear as a solution for public policies, and

102 the master plans began to operationalize the technical and political bases for a development 103 more aligned with the protection of natural resources (ROSA et al. 2019; PROCOPIUCK et 104 al. 2020). The attention of researchers and technicians started to tend to transcend 105 watercourses to solve problems from a broader contextual perspective (GELDOF 1995; POMPÊO 2000; PROCOPIUCK e ROSA 2015). This change in focus occurred because the continuous urban growth had resulted in several negative environmental impacts, such as, for example, the increase of impermeable areas (HATT et al. 2004) generating the increase of

109 runoff, and the transport of pollutants to bodies of water, which has led to the compromise of 110 riparian natural ecosystems.

111 The increased use of impermeable surfaces that go with urban growth has increased

112 the volume of rainwater drained and the transport of polluting solid waste transported by 113 water to the receiving water bodies. One of the reactions to these problems was that

114 stormwater management in urban areas became a priority for new urban water planning and 115 management projects (LUCKE e NICHOLS 2015). This increase in attention to urban water management opened spaces for bioretention techniques for emerging urban drainage systems

117 to become fundamental to mitigate the problems caused by urbanization, promoting the 118 improvement of water quality through collection systems, considering the different levels of 119 development of urban infrastructure (BARBOSA et al. 2012). Over time, these techniques 120 have advanced and generate alternatives for the management of water resources and 121 environmental protection in complex contexts (MCCLEARY e HASSAN 2008; GESSNER et 122 al. 2014). 
125 manage rainwater for reduce peak flows and downstream pollution loads (LUCKE e

126 NICHOLS 2015). Also, such systems are used to remove nitrogen from urban rainwater

127 (WANG et al. 2017; RAHMAN et al. 2020) and eliminate nutrients from rainwater (LUO et

128 al. 2020). The studies also advance to the operation, maintenance, and performance

129 evaluation (DE MACEDO et al. 2017; JIANG et al. 2019; LOPEZ-PONNADA et al. 2020)

130 and others for modeling bioretention systems (JIANG et al. 2019; ALIKHANI et al. 2020) are

131 advancing. The main reasons for the recent popularity of bioretention systems have been the

132 flexibility of their design, which helps in their relatively simple integration in urban areas, and

133 because they work as supplements to provide aesthetic and social benefits in addition to

134 conventional rainwater management functions (CHAHAL et al. 2016).

Bioretention systems have their structure and operation generally based on plants and soil. This base works as a filter medium (usually sand), with the gravel to form a drainage layer and a plant layer as a retention medium (SAMPLE et al. 2014; LI e DAVIS 2016). The systems can be assembled with any type of geotextile to allow infiltration or include an

139 impermeable coating to help capture rainwater and reuse it (FAWB 2009). The captured

140 rainwater is treated through a variety of physical, chemical, and biological processes, such as,

141 for example, mechanical filtration, sedimentation, adsorption, absorption, and microbial plant

142 (MULLANE et al. 2015). However, there are still some difficulties to be overcome for the 143 implementation of bioretention techniques. These difficulties involve finding variables and 144 adjusting the system to them. These variables are, for example, close to water bodies, built 145 areas, conservation areas, and soil type. Besides, the points of contribution and the climatic 146 characteristics of the region must be observed and studied thoroughly to meet the standards 147 required to increase the efficiency of the bioretention process (DOKULIL 2016). understand the complex interaction of hydrological mechanisms (ZALEWSKI 2002), such as, 
150 for example, the establishment of connections between ecological paths and processes, use of 151 ecological systems, hydrological structures, and types of land use and occupation. 152 (ZALEWSKI 2000; LIU 2011; ZALEWSKI et al. 2016). Geoprocessing tools, in turn, assist 153 in urban planning and area management in its various aspects, allowing the interpretation of 154 the surface data (MOURA e PROCOPIUCK 2020) by satellite images for mapping urban 155 areas, showing different levels of details and spatial spectrum (MARTIN-MIKLE et al. 2015). In this article, we aim to evaluate the susceptibility of an area to the implementation

157 of compensatory techniques through the eco-hydrological and geoprocessing basis. The 158 method addresses the observation of local characteristics, the entry of catchment areas, the 159 construction of bioretention systems, the quality of the water in the system, and its possible 160 interference in the basin. In the case of flood events, the assessment is technically oriented 161 with the use of GIS to raise images and maps that describe pre-established situations and 162 future scenarios, determining the $\mathrm{CN}$ (Curve Number) average for sub-areas.

1642 Methods

The data and information collection needed for this study involved the following steps: (I) identification of areas that are adversely affected by flooding events; (II) defining the time interval needed to assess growth and urbanization of the area from satellite images; and (III) construction of thematic maps from digital images to identify different situations using a geoprocessing tool so that the identified classes were represented spatially. cover; (II) area used for reforestation for commercial purposes; (III) area occupied by

173 buildings; (IV) paved areas for people to transit; and (V) areas with low vegetation and bare 174 ground. 
176 for processing and processing digital data. The GIS incorporated data frame layers for

177 Permanent Preservation Areas (APP) and Legal Reserve Area (RL). The developed Hydro 178 APP layers considered the distance of 50 meters from the source and 30 meters from the 179 drainage areas. These distances follow the guidelines proved on the new Brazilian Forest 180 Code (BRAZIL, 2012). A polynomial file was created, and the types of land cover were delimited (I to V described above). Through some image analysis of Google Earth® from 2004 and 2010, a comparison can be made and, thus, assess the incremental change year by 183 year.

\subsection{Study Area}

Brazil, and makes part of Mineirinho's River Basin. This river supplies $40 \%$ of the water demand of the city of São Carlos (Figure 1).

The total campus area increased to 102.4 ha with the addition of another 29.4 ha

194 when the university officially opened on April 11, 2005. At that time, there was also the

195 recovery of legal reserves and Permanent preservation of the surroundings (BENINI 2005).

196 Initial support surveys have indicated that the campus's current drainage system is 197 insufficient, as there is periodically flooding of various areas of the campus throughout the 198 year. There are eight critical areas identified with inadequate drainage. This article deals with 199 the implementation of Compensation Techniques (TCs) at these points. । 
As the Mineirinho River has not yet received a classification from the competent 201 bodies. Considering the current conditions according to the method developed by Zaffani (2012), Negrão (2015), and Aprígio (2012), we classify this river as class 2. According to Resolution No. 357, of March 17, 2005, of the National Environment Council (CONAMA), which established criteria for the classification of surface water bodies and environmental guidelines for their structure, as well as the discharge conditions and standards effluents, Class 2 rivers can be used to (a) The supply for human consumption after conventional treatment; (b) The protection of aquatic communities; (c) The primary contact recreation such as swimming, water skiing, and diving; (d) The irrigation of vegetables, fruit trees, and parks, gardens, sports, and leisure fields, with which the public might have direct contact with; and (e) Aquaculture and fishing activity.

\subsection{Runoff Calculation - CN Method}

One of the simplest and most used methods to estimate runoff volume (effective rainfall) resulting from a rainfall event is the method developed by the National Resources Conservation Service of the U.S. (1972) (formerly Soil Conservation Service - SCS). In this method, after determining the total drained volume, one must calculate the peak flow. The Drainage City Manual of São Paulo, version 2012, recommends the use of a rational method for basins with less than three $\mathrm{km}^{2}$. As the application of bioretention catchments occurs even in the micro drainage level, the recommendations of the manual and the rational method for calculating the drained peak flow were used. First, it was calculated from the total runoff volume from the determination of effective precipitation, based on Eq. 1 and 2. 
$S=\frac{25400}{C N}-254$

225

226

227

228

229

230

231

232

233

234

235

236

237

238

239

240

241

242

243

244

245

246

Where: $\mathrm{P}$ is the total precipitation in the área; $\mathrm{Pe}$ is the effective precipitation; $\mathrm{S}(\mathrm{mm})$ is the ground retention potential, and $\mathrm{CN}$ is the coefficient number.

The $\mathrm{CN}$ value represents the soil coverage conditions and varies from a very permeable cover (lower limit value $=0$ ) to a completely impermeable cover (upper limit value $=100$ ). The hydrological group of the soil and its use and occupation were used as input data. Eq. 3 provided the value of $\mathrm{CN}$ os for cases where there was more than one group of land or use and occupation.

(1)

$$
C N=\frac{\sum A_{i} \times C N_{i}}{\sum A_{i}}
$$

Where $A_{i}$ is the i-th portion of the basin which has the $C N_{i}$ coefficient ; $C N_{i}$ is the coefficient of the $\mathrm{i}$-th portion of the basin.

The peak drained flow was then calculated using the ratio method. The determination of the runoff coefficient $(\mathrm{C})$ results from the ratio between the total volume of precipitation and the total volume drained, that is, the ratio between precipitation and effective precipitation, as shown in Eq. 4 (KAWATOKO 2012). This proportion represents the percentage of runoff generation for the contribution interest area. From $\mathrm{C}$ referring to the contribution area and the intensity of the rains, it was possible to obtain the peak flow drained, as shown in Eq. 5.

$C=\frac{P e}{P}$ Eq.4

$Q_{\text {peak }}=$ C.i.A Eq.5

\subsection{Water quality}


250 Bioretention system. The collected samples had the function of improving the system (Figure

$2512 \mathrm{a})$ within the Bioretention system, here called "storage" (Figure 2b) and with the 252 disqualification of the Bioretention system (Figure 2c). Samples were collected every five 253 minutes by an automatic sampler at the improvement site, in order to obtain the concentration 254 in the wash load, following the procedure created by Silva and Nazareno (2009). Samples were collected every 20 minutes throughout the rainy season for storage and downgrading sites.

Figure 2

The mass balance, to calculate the efficiency of the bioretention system, was done through Eq. 6, adapted from Erickson et al. (2013).

Where: $\mathrm{M}_{\mathrm{s}}(\mathrm{t})=$ Pollutant's mass stored inside the bioretention system; $\mathrm{M}_{\mathrm{in}}(\mathrm{t})=$ Inflow pollutant's mass trough runoff; $\mathrm{M}_{\mathrm{P}}(\mathrm{t})=$ Inflow pollutants' mass trough precipitation; $\mathrm{M}_{\mathrm{I}}(\mathrm{t})=$ pollutant's mass infiltrated/treated by the $\mathrm{CT} ; \mathrm{M}_{\text {out }}(\mathrm{t})=\mathrm{CT}$ 's Outflow pollutant's mass; $\mathrm{t}=$ interval time.

The variables studied on water quality were chosen based on the literature. Some previous research, such as de Barbassa (2014) and Vasconcelos (2008), dealt with rainwater drained by a roof in the peripheral region of São Carlos, concluding that the main pollutants of organic contamination by nutrients and metals.

Currently, a significant part of studies in this area has analyzed the effects of CT in 273 the treatment of metals (HATT et al. 2009; WANG et al. 2017; LI et al. 2018). The following 274 parameters on metallic contamination served as a comparative basis for the efficiency of the 275 Bioretention system that we studied with results from studies on other locations: iron $-\mathrm{Fe}$, zinc $-\mathrm{Zn}$, lead - $\mathrm{Pb}$, nickel - Ni, manganese - Mn copper - $\mathrm{Cu}$, chromium - $\mathrm{Cr}$ and cadmium - 
$277 \mathrm{Cd}$. The three data series of the Bioretention system originate from three rainy events in the 278 dry season in Brazil, with the collection carried out in the hydrographic basin of the Mineirinho River.

Table 1 shows the data for controlling the mass balance time and the sample collection period to determine the concentration at points 1 and 5 .

The time control applied to this balance was the same as the duration of the entry occurrence. However, this period is much longer than the time covered by the sample collection for the concentration measurements. The Event Mean Concentration (EMC) (Eq. 7) this problem.

$290 \quad E M C=\frac{\int C_{t} \cdot Q_{t} \cdot d_{t}}{\int Q_{t} d_{t}}=\frac{\sum C_{t} \cdot Q_{t} \cdot \Delta t}{\sum Q_{t} \Delta t}$ Eq. 7

Where the $\mathrm{C}_{\mathrm{t}}$ and $\mathrm{Q}_{\mathrm{t}}$ are the analyzed concentration parameters and the flow rate, at time $\mathrm{t}$, respectively, and $\Delta t$ the interval of each sample collation.

In theory, the event load is calculated by Eq. 8 and can be simplified to Eq. 4.9 :

$295 \quad$ Load $=Q_{m} \cdot$ C. $\Delta t_{c}$ Eq.8

296 Total Load $=$ EMC. $V_{t}$ Eq.9

297 Where $Q_{m}$ is the mean flow rate, $C$ the concentration and $t_{c}$ the time control.

\section{$3 \quad$ Results and Discussion}

300 The presentation of the results addresses the use of geoprocessing and defines the tools used, the criteria for quantifying land use, the calculation of surface runoff from the study area, the Bioretention based on eco-hydrological principles and, finally, the water quality in bioretention systems. 


\section{$3.1 \quad$ Geoprocessing use}

ArcMap 9.1 software was used to create maps for the classification of land use and occupation, using images captured in 2004, 2010, and 2014 (Figure 3). This period was

309 chosen due to the construction of the university campus, which was when this area underwent

310 significant changes in land use and occupation.

311

312

313

Figure 3

It is possible to identify in Figure 3 the characteristics that indicate the decrease in the permeable area, which can result in the more significant formation of sediments directed to the water body. This mapping also shows the permanence of the low and riparian vegetation over time, showing the preservation despite the moderate changes that occurred in the region. Therefore, the Bioretention techniques to be adopted should mainly support the preservation of these areas.

The map indicates changes in characteristics at the borders of the built area and in reforestation. These changes in land use and occupation morphology imply a decrease in soil permeability, which may also be associated with climatic variations in the region. The study by Gordon and Meentemeyer (2006) demonstrated the effects of urban drainage systems on soil vegetation, with the formation of climatic nuclei in regions where the built areas confronted riparian forests and altered the local environment. Therefore, the flow associated with soil disturbance can have a significant impact on the local environment.

The variables identified in the characteristics of the maps strongly justify the flood zones and suggest that conventional drainage methods would not cause improvements in the region. The map patterns suggest that urban drainage techniques by bioretention should 
330 consider the hydro-geomorphological and eco-hydrological processes and also the

331 relationship between discharge and sediment carried out in its construction stage.

\section{$333 \quad 3.2 \quad$ Use Quantification}

The image processing allowed the identification and quantification of the types of land use and occupation on campus 2 at USP São Carlos (Table 2).

337

338

339

Table 2

The data in Table 2 show that there was an increase in the built and paved areas and the forest cover area over the years. It is possible to infer that there was an increase in the waterproofed area within the campus, with the increase in paved and built areas, going from $3.78 \%$ to $14.44 \%$ of the total area. The increase in the built-up area reflected in the increase in soil sealing and, consequently, in the increase in water runoff. Therefore, there is a more significant amount of sediment transported at a higher speed to the receiving water body, and this can increase its level of sedimentation.

In 2014 , the sealed area represented approximately $14.44 \%$ of the total of Campus 2 , and the protected reserve area represented $20.7 \%$ of the campus. According to the Brazilian Forest Code, the legally required area is $20 \%$, which leaves approximately $0.7 \%$ of the area for the implementation of technical infrastructures that allow better water flow, such as Bioretention systems.

The results of previous research on the characterization of the Ribeirão Mineirinho Basin show that Campus 2 followed a similar pattern of land use occupation to other areas of the basin, increasing the impermeable areas with the construction of paved roads and buildings. Benini's (2005) work shows that pastures and grasses covered about $75 \%$ of the permeable area in 1972 and that just over 5\% was impermeable. This scenario changed in 
2000 , with the impermeable areas increasing to $35 \%$ and the areas covered by grass less than half. The remaining forest areas decreased from just over $10 \%$ to approximately $5 \%$. The study by Aprígio (2012) shows that, in 2012, about 45\% of the area was occupied with buildings, maintaining $20 \%$ of grasses.

The data obtained from the construction of maps to show land use and occupation at

Campus 2 show that this urbanized space showed moderately accelerated growth, with an increase of about $10 \%$ in impermeable areas and, consequently, reducing areas with vegetation. This demonstrates the need for future planning.

364

365

366

367

368

369

370

371

372

373

374

Table 3

Table 4

Table 3 and Table 4 present data on the historical evolution of the legal reserve areas (RL) and permanent preservation areas (APP). These data will be used to establish a correlation with the emerging patterns of photointerpretation. In technical terms, there was no change in the identification method to the corresponding data collected, indicating that the patterns are related to the decrease in the drainage area of the region. This decrease in the area reflects the increase in the transport of solids by runoff to the water body. Unlike the surrounding region (BENINI 2005; APRÍGIO 2012), it is possible to notice that there was an increase in the forest cover area for Campus 2 over the years, with the APP and RL soil vegetation being converted to forestry vegetation. This behavior demonstrates the concern of the university administration with the improvement of the environmental quality and with the commitment to follow the Brazilian environmental legislation.

\subsection{Calculation of runoff}

The calculation of peak flow with the CN-SCS method combined with the ratio method confirmed and quantified the increase in surface runoff, using different $\mathrm{CN}$ values for 
384 all areas of land use and occupation. The calculation of the overall value of the CN used Eq. 3 385 and the peak flow. The flow was calculated with Eq. 4.5. Following the recommendation of

386 the Drainage and Rainwater Management Manual (São Paulo, 2012) for micro drainage, the 387 calculation considered the rain intensity of $91.7 \mathrm{~mm} / \mathrm{h}$ with rain time of $20 \mathrm{~min}$ (most 388 common in the city of São Carlos) and response time of 10 years. With these input values, the 389 precipitation value obtained was $30.6 \mathrm{~mm}$.

$390 \quad$ Calculations of $\mathrm{CN}$ distribution and expert analysis allow us to conclude that $\mathrm{CN} 77$ 391 shows forests in poor condition, CN 91 areas occupied by industrial districts (72\% 392 waterproofing), $\mathrm{CN} 79$ pasture areas in average conservation conditions, and the $\mathrm{CN} 73$ 393 Permanent Protection Areas (APP), which are forests in good condition.

394 The forecast for future scenarios of urban drainage conditions on the Campus 395 complemented the analysis of the increase in the surface runoff with the increase in urbanization, considering the occupations authorized by the Master Plan for Area 2 of the

397 Campus, in the city of São Carlos. The CN calculations and peak drained flow projected three 398 future scenarios: 2025 (50\% occupancy), 2050 (75\% occupancy), and 2100 (85\% occupancy)

399 (Figure 4). These three scenarios were designed with the $\mathrm{CN}$ values previously determined, 400 except the Permanent Preservation Areas. In this case, the use of $\mathrm{CN} 77$ designed forests in poor condition.

402

403

404

405

406

407

408

409

\section{Figure 4}

Table 5 shows the flow scenarios obtained for each of the eight hydrographic basins (contribution areas) that cover the study area. The calculation of the maximum drained flows was carried out based on the $\mathrm{CN}$ values for each contribution area, varying according to the percentage of campus occupation. The results presented illustrate how changes in land use and occupation affect runoff. It can be noted that the campus occupation would double in size 
410 between the years 2014 and 2025, leading to a percentage increase in runoff ranging from

$41113 \%$ (basin 5) to $100 \%$ (basin 7). The maximum expected increase is $214 \%$ in basin 7 for 412 scenario 2100, with a higher occupancy rate.

413

414

415

416

417

418

419

420

421

422

423

424

425

426

428
Table 5

The mapped scenarios denote a significant increase of the impermeable area through the classes that indicate constructed areas and by the objects that indicate road expansion. Under these conditions, after local consultations, it can be noticed an increase in volumes of water running into the river studied. Additionally, the hydrological performance can also be compromised over time, because, besides the running, the cycle as a whole is influenced by the permeability coefficients.

\section{4 bioretention based on ecohydrological principles}

The dimensions of the Bioretention system followed the criteria of general efficiency and joint performance and can be verified by comparing the qualitative and quantitative efficiency. In this work, only qualitative results will be shown, guided by eco-hydrological principles, as shown in Figure 5, which is illustrative and is not on the scale. The diagram shows the contribution areas of the hydrographic basin studied concerning the Bioretention technique, the zones of influence that emerge from the urban growth of the region, that the Mineirinho River has dense riverside vegetation and small pockets of water along its route, and that the contribution flow is basically from the campus drainage system and rainwater harvesting. All of these components are evaluated in correlation with ecosystem interactions. Figure 6 shows the constructive parameters of the implementation of the Bioretention project. 


\section{Figure 5}

Figure 6

The proposed system allows this temporal assessment to be scaled in a modular way, and without much effort to expand its size over time. These conditions are necessary because the study area is recent and is in full expansion, that is, the more urbanized space, the greater the flow and, therefore, the greater the Bioretention system.

\subsection{Water quality in bioretention Systems}

Some analyses of water quality were made at three points in this bioretention experiment - inlet, storage, and outlet - in order to characterize the pollution present in the surface runoff and evaluate the efficiency of the technique in removing pollutants. Three rainfall events were considered, in August and September 2015. Table 6 also shows, for means, characteristics of events.

\section{Table 6}

The Table 7 shows the EMC obtained for the variables: $\mathrm{Fe}, \mathrm{Zn}, \mathrm{Pb}, \mathrm{Ni}, \mathrm{Mn}, \mathrm{Cu}, \mathrm{Cr}$ and $\mathrm{Cd}$, and shows, for means of comparison, the standards established for the effluent released in a Class 2 river, which is Mineirinho's class, according to Brazilian Federal CONAMA 357/2005 resolution. It can be observed that the outlet EMC for $\mathrm{Fe}, \mathrm{Ni}, \mathrm{Cu}$, and $\mathrm{Cd}$, at all three events, and for $\mathrm{Pb}$, in events 2 and 3, presents higher values than the limits established by the CONAMA. However, the total inlet and outlet mass of the parameters should be analyzed to verify the bioretention efficiency and how this system reduces the impact on the receiving water body. 
The rainfall measurements were $6.0 \mathrm{~mm}$ in the first event, $3.0 \mathrm{~mm}$ in the second event, and $39.0 \mathrm{~mm}$ in the third event. Figure 7 shows the accumulated and instantaneous erosion.

\section{Figure 7}

The inlet and outlet mass of each parameter analyzed, and the removal efficiency is shown in Table 8. It shows the removal efficiency for the monitored events. It is possible to notice, for most of the parameters analyzed, that the practice decreases the pollutant load, which would have reached the water body, considerably. The chrome concentration measured was insignificant, and it is not shown in the table.

The metal removal efficiency varies from $40.3 \%$ to $97.8 \%$. The lead was the parameter with the higher removal rates $(94.0 \%$ and $91.8 \%$ for the events 1 and 2$)$. Iron had the worst removal efficiency: $40.3 \%$ in event 1 , and it had even, for event 3 , a higher outlet mass than inlet, resulting in a negative efficiency $(-74.84 \%)$. This can be explained due to the Brazilian soil chemical composition. Due to the geological characteristics and its high weathering levels in tropical regions, it is common to find high iron oxides in the soils like the one used to the superficial and vegetated layer of the $\mathrm{CT}$ in which an erosion occurrence was observed during the event 3 . Besides the iron, all other metals, in event 3 , had a lower removal efficiency when compared to the events 1 and 2 . The reason might also be linked to 
To complement the results analysis, a review of the metal removal rates obtained by

497 other authors was performed. Wang et al. (2016) studied Cd removal in several filtrating materials and had over $95 \%$ of efficiency. Wang et al. (2015) also evaluated the $\mathrm{Cu}, \mathrm{Pb}$, and

Cd removal by filtration of wastes from construction sites and obtained more than $90 \%$ of

500 efficiency. These values are much higher than those found in this study. However, Wang et al.

$501(2016 ; 2017 ; 2018)$ did these studies under a laboratory scale with no adversities faced in a

502 field experiment. Hatt et al. (2009), otherwise, analyzed the removal efficiency of a bioretention system applied to the field and obtained an efficiency of $67 \%$ and $80 \%$ for $\mathrm{Cu}$ and $\mathrm{Pb}$, respectively. It is essential to highlight, that the removal efficiency of a bioretention system varies with its location, due to the different climate conditions and the filtrating material characteristics, as the vegetated layer has a significant influence on the runoff treatment.

Although the Mineirinho's River Basin be classified as a Class 2 - under Brazilian law, which allows for a more noble use of its waters such as supply for human use and

510 primary contact recreation, Aprígio (2012) found the illegal contribution of domestic sewage

511 in regions on its head. This may contribute to a loss of environmental quality of the basin, an

512 increase of pollutant concentration in its water, and risks to the surrounding population. Thus, some actions to reduce the amount of pollution and consequent improvement in water quality

514 to match its intended uses are essential for this region.

\section{Conclusion}

The method used to map the use and occupation of land allowed to verify and 
520 the criteria to define the study area were satisfactory and provided a study model and 521 characterization of the area - more comprehensive and accurate to select sites for construction 522 of bioretention techniques - based on ecohydrological principles. The mapping of land use 523 and occupation groups simplifies the procedures for integrating information regarding the 524 priority areas for the construction of bioretention systems and the particular characteristics of 525 each region, providing the implementation of resource of georeferenced bases directed to ecohydrological issues.

The comparative visual analysis allows an initial assessment, although more superficial, on the quality of the method applied to determine the $\mathrm{CN}$. It is noticeable that 529 there are more significant $\mathrm{CN}$ values in more urbanized areas, where waterproofing 530 percentage is high, associated with soil conditions showing infiltration capacity below the average. The regions of forests and fields are clear indicators of areas where there is less runoff (lower CN).

The increase in impermeable areas, even with a slow rate of advancement, increases

534 the quantities of sediments during periods of heavy rainfall, making a high input of sediments 535 in the receiving body, causing the increase of various parameters related to water quality and 536 peak flow. With the implementation of compensatory techniques, this problem is mitigated, lowering the impact in water ecosystems downstream of the bioretention technique.

539 improvement in the analyzed parameters. It was possible to verify that there is a decrease in 540 the mass loading and, accordingly, improvement in water quality parameters, which 541 contributes to the lower of pollutants and contaminants to the receiver. This feature reinforces 542 the capacity of the treatment of the bioretention technique.

543 Guided by our studies, we can say that applying this methodology to select areas to 544 implement the bioretention system is efficient and proves, with the data presented, the 
545 reduction of pollutant load directed to the river, being understood that the construction of 546 bioretention techniques, in addition to not impacting the river, brings benefits to it. This is

547 justified by the thematic maps, where one can see that there is considerable natural vegetation 548 covering the area, as well as areas that were reforested over time. As for the quality of the 549 output effluent from the bioretention system, it is possible to verify that there is a significant 550 improvement of the analyzed parameters.

The study clearly shows the importance of using a georeferencing tool for analysis of areas since it enables rapid and consistent analysis of the study area. When correlation occurs with ecohydrological indicators, the perception of the process efficiency supported with

554 physical elements becomes believable when it is noticed. An example is the investigation of vegetal areas, that together with the results of qualitative parameters, demonstrate that the implementation of a bioretention system attenuates the peak flow effects for a specific region. Studies of this size can support a feasibility analysis and is more accurate in efficiency for regions with different climatic and physical characteristics.

\section{Acknowledgements}

The authors acknowledge the support of projects: (1) MAPLU2 - Stormwater

Management in Urban Environment/FINEP, (2) Thematic Project 2008/15161-1 FAPESP

564 "Advanced monitoring of biotechnological processes and environmental quality" and (4)

565 CNPq 307637/2012-3 of Scientific Productivity.

$567 \quad 6 \quad$ Funding

This research was funding by the projects: (1) MAPLU2 - Stormwater Management in

569 Urban Environment/FINEP, (2) Thematic Project 2008/15161-1 FAPESP “Assessment of 570 Impacts and Vulnerability to Climate Change in Brazil and Strategies for Adaptation Options" 


\section{$7 \quad$ Authors contribution}

Altair Rosa: Conceptualization, Investigation, Visualization, Writing - original draft; Mario Procopiuck: Writing - Review \& Editing; Marina Batalini de Macedo: Investigation, Formal analysis; David Sample: Supervision; César Ambrogi Ferreira do acquisition; Mario Eduardo Mendiondo: Supervision, Project administration, Funding acquisition.

\section{$8 \quad$ Competing interests}

The authors have no competing interests to declare.

\section{$9 \quad$ Availability of data and materials}

The data used in this study are not organized in a parameterized database in a relational bank for availability for automatic processing. However, to databases in multiple spreadsheets, they can be made available, in .xlsx format, upon request by email: altair.rosa@pucpr.br

\section{REFERENCES}

Alikhani, J.; Nietch, C.; Jacobs, S.; Shuster, B. e Massoudieh, A. Modeling and Design Scenario Analysis of Long-Term Monitored Bioretention System for Rainfall-Runoff Reduction to Combined Sewer in Cincinnati, OH. Journal of Sustainable Water in the Built Environment, v.6, n.2. p.04019016. 2020. D.O.I: DOI:10.1061/JSWBAY.0000903. APRÍGIO, P.d.O. Evaluation of diffuse loads simulation models in an urban watershed. 2012. (M.Sc. Dissertation).Orientador: BRANDÃO, J.L.B.School of Engineering at São Carlos, University of São Paulo, São Carlos

600 Barbassa, A.P.; Angelini Sobrinha, L. e Moruzzi, R.B. Poço de infiltração para controle

601 de enchentes na fonte: avaliação das condições de operação e manutenção. Ambiente 602 Construído, v.14, n.2.p.91-107. 2014

603 Barbosa, A.E.; Fernandes, J.N. e DAVID, L.M. Key issues for sustainable urban stormwater 

https://doi.org/10.1016/j.watres.2012.05.029. BENINI, R.M. Scenarios of urban occupation and its hydrologic impacts in the Mineirinho river basin. 2005. (M.Sc. Dissertation).Orientador: MENDIONDO, E.M.School of Engineering at São Carlos, University of São Paulo, São Carlos

609 Chahal, M.K.; ShI, Z. e FluRY, M. Nutrient leaching and copper speciation in compostamended bioretention systems. Sci Total Environ, v.556. p.302-309. 2016. D.O.I: 10.1016/j.scitotenv.2016.02.125.

612 DE Macedo, M.B.; Rosa, A.; do Lago, C.A.F.; Mendiondo, E.M. e de SouzA, V.C.B. 613 Learning from the operation, pathology and maintenance of a bioretention system to optimize 614 urban drainage practices. Journal of Environmental Management, v.204. p.454-466. 2017. 615 D.O.I: https://doi.org/10.1016/j.jenvman.2017.08.023.

616 DokULIL, M.T. Climate impacts on ecohydrological processes in aquatic systems. 617 Ecohydrology \& Hydrobiology, v.16, n.1. p.66-70. $2016 . \quad$ D.O.I: 618 https://doi.org/10.1016/j.ecohyd.2015.08.001.

619 FAWB. Guidelines for filter media in biofiltration systems (Ver. 3.01). Melbourne: Facility 620 for Advancing Water Biofiltration, June 2009. GELDOF, G.D. Adaptive water management: Integrated water management on the edge of chaos. Water Science and Technology, v.32, n.1. p.7-13. 1995 . D.O.I: http://dx.doi.org/10.1016/0273-1223(95)00532-R. GESSNER, M.O.; HinKelmANN, R.; NÜTZMANN, G.; JEKEl, M.; SingER, G.; LEWANDOWSKI, J.; NEHLS, T. e BARJENBRUCH, M. Urban water interfaces. Journal of Hydrology, v.514. p.226232. 2014. D.O.I: http://dx.doi.org/10.1016/j.jhydrol.2014.04.021. GORDON, E. e MEENTEMEYER, R.K. Effects of dam operation and land use on stream channel morphology and riparian vegetation. Geomorphology, v.82, n.3. p.412-429. 2006. D.O.I: https://doi.org/10.1016/j.geomorph.2006.06.001. HATT, B.E.; FLETCHER, T.D. e DELETIC, A. Hydrologic and pollutant removal performance of stormwater biofiltration systems at the field scale. Journal of Hydrology, v.365, n.3. p.310321. 2009. D.O.I: https://doi.org/10.1016/j.jhydrol.2008.12.001.

633 HATT, B.E.; FletChER, T.D.; WALsh, C.J. e TAYLOR, S.L. The Influence of Urban Density 634 and Drainage Infrastructure on the Concentrations and Loads of Pollutants in Small Streams. 635 Environmental Management, v.34, n.1. p.112-124. 2004. D.O.I: 10.1007/s00267-004-0221-8.

636 JIANG, C.; LI, J.; LI, H. e LI, Y. Experiment and simulation of layered bioretention system for 637 hydrological performance. Journal of Water Reuse and Desalination, v.9, n.3. p.319-329. 2019. D.O.I: 10.2166/wrd.2019.008 \%J Journal of Water Reuse and Desalination.

640 KAWATOKO, I.E.S. Establishment of non-structural measures as tools for urban water management in school lot. 2012. (M.Sc. Dissertation).Orientador: MENDIONDO, E.M.School of Engineering at São Carlos, University of São Paulo, São Carlos LI, J. e DAVIS, A.P. A unified look at phosphorus treatment using bioretention. Water Research, v.90. p.141-155. 2016. D.O.I: https://doi.org/10.1016/j.watres.2015.12.015. LI, J.; LIANG, Z.; LI, Y.; LI, P. e JIANG, C. Experimental study and simulation of phosphorus purification effects of bioretention systems on urban surface runoff. PLOS ONE, v.13, n.5. p.e0196339. 2018. D.O.I: 10.1371/journal.pone.0196339. LIU, H.-H. Impact of climate change on groundwater recharge in dry areas: An ecohydrology approach. Journal of Hydrology, v.407, n.1. p.175-183. 2011. D.O.I: https://doi.org/10.1016/j.jhydrol.2011.07.024.

650 LOPEZ-PonNADA, E.V.; LYNN, T.J.; ERGAS, S.J. e MiHELCIC, J.R. Long-term field performance of a conventional and modified bioretention system for removing dissolved nitrogen species in stormwater runoff. Water Research, v.170. p.115336. 2020. D.O.I: https://doi.org/10.1016/j.watres.2019.115336. 
LUCKE, T. e NiCHOLS, P.W.B. The pollution removal and stormwater reduction performance of street-side bioretention basins after ten years in operation. Science of The Total Environment, v.536. p.784-792. 2015. D.O.I: https://doi.org/10.1016/j.scitotenv.2015.07.142. LuO, H.; GuAN, L.; JiNG, Z.; HE, B.; CAO, X.; ZhaNG, Z. e TAO, M. Performance Evaluation of Enhanced Bioretention Systems in Removing Dissolved Nutrients in Stormwater Runoff. Applied Sciences, v.10, n.9. p.3148. 2020

660 MARTIN-Mikle, C.J.; DE Beurs, K.M.; Julian, J.P. e MAYER, P.M. Identifying priority sites for low impact development (LID) in a mixed-use watershed. Landscape and Urban Planning, v.140. p.29-41. 2015 MCCleary, R.J. e HaSSAN, M.A. Predictive modeling and spatial mapping of fish distributions in small streams of the Canadian Rocky Mountain foothills. Canadian Journal of Fisheries and Aquatic Sciences, v.65, n.2. p.319-333. 2008. D.O.I: 10.1139/f07-161.

667 MourA, E.N. e ProcopIUCK, M. GIS-based spatial analysis: basic sanitation services in Parana State, Southern Brazil. Environmental Monitoring and Assessment, v.192, n.2. p.96. 2020. D.O.I: $10.1007 / \mathrm{s} 10661-020-8063-2$.

670 Mullane, J.M.; Flury, M.; IQbal, H.; Freeze, P.M.; Hinman, C.; Cogger, C.G. e Shi, Z. Intermittent rainstorms cause pulses of nitrogen, phosphorus, and copper in leachate from compost in bioretention systems. Science of The Total Environment, v.537. p.294-303. 2015. D.O.I: https://doi.org/10.1016/j.scitotenv.2015.07.157. NEGRÃO, A.C. One-dimensional hydrodynamic modeling of flood wave passage in an urban stream considering. 2015. (M.Sc Dissertation).Orientador: REIS, L.F.R.University of São Paulo, School of Engineering at São Carlos, Sao Carlos PoMPÊO, C.A. Drenagem urbana sustentável. Revista Brasileira de Recursos Hídricos, v.5, n.1.p.15-23. 2000 ProcopiUCK, M. e RosA, A. Evaluation of communities' perception on public policies, urban rivers functions, and qualities: the Belém River case in Curitiba. Urban Water Journal, v.12, n.7. p.597-605. 2015. D.O.I: 10.1080/1573062X.2015.1024690.

Procopiuck, M.; Rosa, A.; Bollman, H. e MourA, E.N. Socially evaluated impacts on a technologically transformed urban river. Environmental Impact Assessment Review, v.85, n.1. 2020

684 RAHMAN, M.Y.A.; NACHABE, M.H. e ERGAS, S.J. Biochar amendment of stormwater bioretention systems for nitrogen and Escherichia coli removal: Effect of hydraulic loading rates and antecedent dry periods. Bioresource Technology, v.310. p.123428. 2020. D.O.I: https://doi.org/10.1016/j.biortech.2020.123428. Sustainable urban drainage: delineation of a scientific domain of knowledge production. Revista Tecnologia e Sociedade, v.15, n.38. p.18-36. 2019. D.O.I: 10.3895/rts.v15n38.9017. Sample, D.; LuCas, W.; Janeski, T.; Roseen, R.; Powers, D.; Freeborn, J. e Fox, L. Greening Richmond, USA: a sustainable urban drainage demonstration project. ICE Virtual Library, v.167, n.2. p.88-95. 2014. D.O.I: 10.1680/cien.13.00036. SERVICE., U.S.S.C. SCS National Engineering Handbook, Section 4: Hydrology. The Service, 1972.

Silva, L.A. e NAZARENo, N.R.X. Análise do padrão de exatidão cartográfica da imagem do Google Earth tendo como área de estudo a imagem da cidade de Goiânia In: XIV Simpósio Brasileiro de Sensoriamento Remoto. Natal: INPE, 2009. p.1723-1730. VASCONCElos, A.F. Análise da qualidade da água pluvial para sistemas de aproveitamento com separadores automáticos. 2008. (Trabalho de Conclsão de Curso).Orientador: MENDIONDO, E.M.Escola de Engenharia de São Carlos, Universidade de São Paulo, São Carlos
WANG, H.; JI, G. e BAI, X. Distribution patterns of nitrogen micro-cycle functional genes and 
their quantitative coupling relationships with nitrogen transformation rates in a biotrickling

705 filter. Bioresource Technology, v.209. p.100-107. $2016 . \quad$ D.O.I: 706 https://doi.org/10.1016/j.biortech.2016.02.119.

707 Wang, M.; Zhang, D.; LI, Y.; Hou, Q.; Yu, Y.; QI, J.; Fu, W.; DOnG, J. e Cheng, Y. Effect

708 of a Submerged Zone and Carbon Source on Nutrient and Metal Removal for Stormwater by

709 Bioretention Cells. Water, v.10, n.11. p.1-13. 2018. D.O.I: 10.3390/w10111629.

710 WANG, S.; LIN, X.; YU, H.; WANG, Z.; XIA, H.; AN, J. e FAN, G. Nitrogen removal from urban

711 stormwater runoff by stepped bioretention systems. Ecological Engineering, v.106. p.340-

712 348. 2017. D.O.I: https://doi.org/10.1016/j.ecoleng.2017.05.055.

713 ZAFFANI, A.G. Diffuse pollution from urban drainage based on ecohydrology: diagnosis and

714 long term scenarios in urban watershed in São Carlos, SP. 2012. (Thesis).Orientador:

715 MENDIONDO, E.M.School of Engineering at São Carlos, University of São Paulo, São

716 Carlos

717 ZALEWSKI, M. Ecohydrology - The Scientific Background to use Ecosystem Properties as

718 Management Tools Toward Sustainability of Water Resources. Ecological Engineering, v.16.

719 p.1-8. 2000. D.O.I: 10.1016/S0925-8574(00)00071-9.

720

721

722

723

724 . Ecohydrology - the use of ecological and hydrological processes for sustainable management of water resources / Ecohydrologie-la prise en compte de processus écologiques et hydrologiques pour la gestion durable des ressources en eau. Hydrological Sciences Journal, v.47, n.5. p.823-832. 2002. D.O.I: 10.1080/02626660209492986.

725

ZALEWSKI, M.; MCClain, M. e Eslamian, S. New challenges and dimensions of

cohydrology - enhancement of catchments sustainability potential. Ecohydrology \& Hydrobiology, v.16, n.1. p.1-3. 2016. D.O.I: https://doi.org/10.1016/j.ecohyd.2016.01.001. 